\title{
POLITICS AND NURSING
}

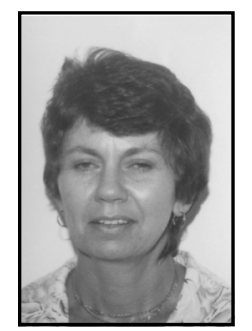

\author{
Susan E van Niekerk \\ MCur with specialisation in Nursing Education \\ Senior Lecturer, Department of Nursing Science \\ University of Pretoria
}

\section{OPSOMMING}

Politiek impliseer die "kuns om besluite te be-invloed" en verpleegkundiges het die politieke verantwoordelikheid om die allokasie van skaars gesondheidshulpbronne te beinvloed. Die konsep van mag en politiek in verpleging hou verband met die hervorming van gesondheidsaangeleenthede, sosio-politiese aangeleenthede soos die beskikbaar stel van fasiliteite vir hoër onderwys in verpleging, en beskikbaarheid van fasiliteite om kwaliteit verpleegsorg in enige gegewe situasie te verseker.

Die enigste manier om te verseker dat verpleegkundiges ' $\mathrm{n}$ bydrae kan maak tot sodanige besluitneming, is hoë standaard opleiding, en daarby ingesluit politiese kundigheid en vaardigheid in die aanwending daarvan.

Die voorbereiding van praktisyns wat toekomstige verandering kan hanteer en inisieer, vereis verandering in die onderwys en opleiding van verpleegkundiges. Die finansiering van gesondheidsorg en opleiding moet veranderinge in die kurrikulum akkommodeer. Die effek van hoë standaarde in verpleegonderwys op die handhawing van gesondheid in die gemeenskap en in die analisering van veranderende gesondheidsbehoeftes word beïnvloed deur die kwaliteit van verpleegonderwys. Verpleegdosente beïnvloed die gesondheidsorg stelsel deur te kontroleer wat en hoe hul onderrig, deur ' $n$ rol-model te wees, en deur kliniese opleidingsfasiliteite te selekteer, waar studente hul vaardighede effektief kan ontwikkel.

\section{ABSTRACT}

Politics implies the art of influencing people, and nurses have the political responsibility to influence the allocation of scarce resources. The concept of power and politics in nursing entails the reform of health issues, socio-political issues such as facilities for effective higher education in nursing, and facilities to enable nurses to render effective patient care in any given situation.

The only way nurses will be allowed to have input in these issues is when they are comprehensively trained according to standards higher than minimum requirements, including education in politics and the application thereof.

Preparing nursing practitioners who can cope with, and who can initiate future health-care issues will require changes in the education of nurses. Nurses should be educated in the financing of health care, and in the important influence quality health care could have on productivity in the country, as well as in analysing the changing needs of the community.

Nursing Educators can and do influence the health-care system by being in control of what they teach, by being role models, and by selecting the clinical sites where they expect students to develop clinical skills. 


\section{INTRODUCTION}

Politics is defined in the literature as "the art of influencing other people (Ker in Delougherry, 1994:477) or "influencing the influential (Yeaworth in Chaska, 1990:534). Many nurses recognise the importance of developing political skills in order to improve the health care of the patients - be it through nursing management, or through effective nursing education.

The objectives of this article is to:

start a debate with regard to the inclusion of politics as an elective subject in post-basic nursing education, and

to emphasise the importance of including the skills to analyse policies and make public statements on matters influencing the nursing profession, in the basic nursing curriculum.

\section{THE NURSING PROFESSION'S RELATIONSHIP WITH SOCIETY}

A professional relationship (with society) involves a direct connection comprising an informal contract between the professional (nurse) and the client (society), for an identifiable service in a particular area of expertise. The view on health from a nursing perspective emphasises the quality of life of the individual, which is more than just the absence of disease. Nursing has a responsibility to society to be involved in the planning and co-ordination of the continuing health care matters of society at large, and in the organisation and implementation of this care, wherever it realises.

Traditionally nursing has always been without any power with regard to national policy-making. Rains \& Kelley (2000:37) refers to Huston's discussion of the factors contributing to the lack of "positive" political action amongst nurses, namely

- the oppression of nurses as a group;

. the invisibility of nursing in mass media;

- the negative connotations nursing ascribe to political activity; and

the tendency towards re-active rather than proactive political action amongst leaders in Nursing.

Historically, nurses have been expected to be subservient, to follow in other's footsteps, e.g. that of physicians. The thought of empowering nurses has only recently been discussed in literature, with the result that nurses have to get used to the concept themselves. The lack of political skills taught as part of the curriculum, has attributed to nurses' lethargic role with regard to health policy, and their being 'workhorses', although they are, according to Conger and Johnson (2000:99) the health system's backbone.

Nurses as a group, need to develop the selfconfidence for assuming positions of leadership, as part of clinical teams, in managerial positions as well as in government. Politics in nursing comprise three levels of power-based actions:

- Interpersonal politics, such as politics in practice, e.g. power-based actions between nurses or nurses and patients.

- Organisational politics, e.g. interactions between dominant groups within the organisation, involving hierarchical power structures.

- External politics, referring to national and governmental policies, and political actions such as lobbying in order to influence legislative policy (Callahan, 2000:34).

Involvement in policy-making and changing of health-care structures presents a challenge to all nurses. Although it is demanding and timeconsuming, it is also enormously worthwhile. The strength in numbers, of nurses acting as a group of health-care providers, could be used to the political advantage of the health-care consumer.

\section{THE VALUE OF POLITICAL KNOWLEDGE FOR NURSING AND NURSING EDUCATION}

The concept of empowerment and politics in nursing 
and nursing education has nothing to do with strikes for own benefit, such as salary improvement or less working-hours. It entails the transformation of healthissues, of socio-political issues such as facilities for effective higher education in nursing, and facilities, which will enable nurses to render effective patient care in any given situation. Nurses need the knowledge and skills to enhance and safeguard the community's health through the influencing of policies that may affect the health of the community (Rains \& Kelley, 2000:37). Nurses should understand the socio-political nature of health policy-making, as well as the ethics of health care decision-making.

The inclusion of politics, and a critical approach to all policy that can influence health and health care delivery, will establish a pattern of understanding as to how political skills and policy development can enhance nursing practice and nurseling's social policy mandate (Conger \& Johnson, 2000:100).

Nurses should be involved in policy-making in order to maintain their control over nursing practice, and have an impact on and access to the delivery of health care. The word 'politics' implies the art of influencing other people, while 'political activity' implies influencing others for the purpose of allocating scarce resources wisely. Although nurses have no direct input into the allocation of available resources (money), they have the political responsibility to provide reasons for the allocation of those resources.

Health care is becoming a scarce resource, and decisions will consequently have to be made about how these scarce resources can be made accessible - nurses must be actively involved in this kind of decision-making, as it will influence their future. Discussions on whether politics should form part of the duties of the nurse should analyse what nursing and it's theoretical foundations entail (De Thornyay, 1993:302). Nursing Theory incorporates physical, social, psychological, cultural, economic, environmental and political factors in a holistic approach, and therefore the study of politics has a legitimate place in nursing courses. Political empowerment of health-care deliverers is an essential ingredient in the education of nurses, and it includes the involvement of individuals in the process of organised action. A 'political powerful voice' must be demonstrated to the community using all available platforms (Taylor, 1995:1180). The spotlight must be on nurses and their competence and excellence in rendering health care in any given situation.

- The clinical situation is the first important platform that should be used to ensure that the public does not underestimate the value of nursing and nurses. The knowledge and skills of nurses should be demonstrated in their interaction with the patient and their professional relationship with other members of the professional community.

- The second platform to be used is the opportunities available in nursing education. Nursing educators should not only acquaint their students with the policies on health care and other related issues, but also instil in students the belief that their involvement can make a difference (Batra, 1992:170). Health policy should be incorporated in the curricula in order to ensure that nursing students will be better equipped for their role as political agents in nursing. Nursing educators should create opportunities for students to participate in the political activities of the nursing organisation while always reflecting a health-care agenda concerned with patient issues, not with nurses' issues.

The only way for nurses to be able to make meaningful contributions in this regard, will be if they are comprehensively trained according to standards higher than minimum requirements; education in politics and how to use it, included (De Thornyay, 1993:305). The basic course in nursing which leads to registration as a nurse, 
equips students to function comprehensively in general nursing, midwifery, community nursing and psychiatric nursing. Emphasis and guidance in certain areas concerning health policy, and purposeful empowerment by means of knowledge and reasoning skills, will equip students at basic level already to be prepared for their future role of shaping nursing and health care to the benefit of the client (Ker in Delougherry, 1995:477).

The inclusion of politics in the nursing curriculum will result in health policy to be regarded as any other policy impacting the health of the population (Glen, 1995:92). Students will develop to think, act and research in ways relevant to policy, and be aware of the clinical impact of policies and strategic planning by professional nursing organisations, to influence health-related issues in politics (Batra, 1992:171).

Nursing Education should prepare nurses to participate intelligently in the political arena, to anticipate the need for change, and to take part in the development of public policy - public policy and politics will then in return, influence the content and resources of Nursing Education.

\section{EMPOWERMENT FOR POLITICAL AND HEALTH POLICY INVOLVEMENT}

Empowerment can be described as "to give power and authority, to enable and to permit." Empowerment ensures a change in attitudes towards the professional setting, in the sense that people begin to realise that they have accountability, commitment to and participation in the organisation, as well as acceptance of responsibility. Brennan refers to Einstein when stating: "The problems we have facing us, need to be solved by different thinking than the thinking that created them" (Brennan, 1993:2). We need to think differently in Nursing, and as such, in Nursing Education. We need to discard old patterns and behaviours, accept challenges, and be willing to take risks. Empowerment comes from within. It is a way of thinking. It calls for inner strength and belief in oneself, for only then will you believe that you have something to give to another. Empowerment is not about having power over another; it is about making a difference. Nurses must recognise that, in order to improve the lot of patients and the community, and to maintain professional freedom and standards, they must ensure a powerful political voice based on knowledge and skills (Taylor, 1995:1181). One way in which nurses can utilise their political voice to the benefit of the patient and the profession is to change the system within which they function. The system includes:

- top management's respect for the knowledge and skills of personnel;

- respect for the nurse as learner and as practitioner through effective continuing education; and

the availability of resources and facilities to enhance the quality of patient care and to generate a learning climate.

\section{ETHICS AND POLITICS}

The concept of politics in nursing is interrelated and interconnected with ethics. Ethics encompasses the whole of life, including our professional conduct to others and the community. Politics has the practice of public ethics as one of its dimensions, - it encompasses all of the complex and often conflicting interrelations amongst people living in society (Aroskar, 1994:129).

Leadership activities of nurses in national healthcare reform efforts provide an example of the intertwining of ethics and politics in the public policy domain. Advanced professional nurses, as part of their ethical functioning, should provide information through various channels to decision-makers in health policy. The impact of political dynamics on the health of consumers, health care itself and the nursing profession should be communicated to public 
and professional audiences.

The interrelation between ethics and politics in the delivery of health care, requires nursing education to examine their objectives in the teaching of ethics in the curriculum. The student nurse in South Africa studies nursing ethics formally during her first and final year of study, and the content is applied informally throughout her training. Examples in this regard are, for instance:

- complex decision-making situations involving social, legal and economic considerations,

creation of learning opportunities in reviewing health policy, and the identification of complex situations in health care that require attention with regard to ethics and politics before making decisions, degree courses should require student nurses to belong to, and be active in professional nursing organisations.

\section{POLITICS AND NURSING EDUCATION}

Knowledge of political processes is essential in enabling nurses to influence decisions. Preparing nursing practitioners to cope with, and initiate future health-care issues, will require changes to the perspectives on nursing education (Yeaworth in Chaska, 1990:535). Nurses will require developed nursing skills, based on conceptual critical reasoning and the use of scientific data. Nurses should also be educated in:

\section{the financing of health care,}

the influence of quality in healthcare, on the productivity of the community, analysing the changing health needs of the community to be able to assess if nursing education still provide in the specific needs of the community.

Nursing Educators can, and do, influence the healthcare system by being in control of what (and how) they teach, by being role models and by selecting the clinical sites where they expect their students to develop their clinical skills. The educator can influence the quality of health care by the way she uses teaching strategies to do subject integration, and by the way she correlates theory and practice in the theoretical teaching situation, as well as in the didactic clinical situation. The nursing educator has part in the development of the safe, skilful professional nurse that the South African community needs. This nurse should be able to:

- participate in the initiation of change in health care influence political changes in nursing cope with future health-care issues develop skills and competencies that reflect an understanding of the changing needs of the community we serve.

\section{LEADERSHIP SKILLS}

Another aspect that should be emphasised with respect to the enhancement of political skills amongst nurses, is the development of leadership skills during basic nursing education and training. In this regard, both the theoretical and the practical skills development should be based on the development of independent functioning, and self-confidence based on knowledge and skills to ensure an empowered force of nurses who can bring about change in health care in political astute ways that will be effective. In order to achieve this goal effective co-operation between Nursing Education and Nursing Services on formal and informal levels is of the essence.

\section{POLITICS AND NURSING EDUCATION MANAGEMENT}

\section{The mobility of students}

Schools of Nursing in South Africa should seek opportunities by which student exchanges or joint arrangements can improve educational quality and better utilisation of scarce resources. Curricula and 
the transfer of credits must be defendable to the public and government. Instead of super specialisation, educators should give more attention to collaboration between nursing schools, to promote student mobility educationally while maintaining quality and maximise economy.

\section{Input into the community}

Nursing Schools must be able to document contributions towards social uplifting in their community through job-creation, grants and other socio-economic inputs. Nursing as a profession must state their contribution to health care and emphasise the need for quality nursing education to enhance the standards of nursing. Clinical learning experiences should be selected not only to allow students to meet learning objectives, but also to increase visibility of the profession's contribution to the welfare of the community.

\section{QUALITY OF EDUCATION}

Different approaches exist to gain political influence but the quality of nursing care that the community is receiving has the greatest impact. Nursing Education has as objective: the development of student nurses into professional skilled practitioners who can render quality comprehensive nursing care in any given situation. Students must be able to lobby for nursing and the welfare of the patient. They must eventually be able to have an active input into the political arena to influence nursing and health-care.

\section{CONCLUSION}

Politics is becoming an essential activity in the nursing profession in affecting policy changes, health care planning and policy making at local, state, or national levels to protect the future of nursing (Brown, 1996:1). Empowerment is the ability and willingness to affect the behaviour of others to bring about change. Nurses are able to exercise power in politics to the benefit of the community, if and when they energise and articulate collectively. The time has come to include politics as an elective subject in the nursing curriculum. It should be included in postbasic nursing courses, and already on a pre-graduate level student nurses should be prepared to take responsibility for shaping the future of nursing as profession and having an active role in the formulation of health care policy in South Africa. Future discussion in this regard is being looked forward to.

\section{BIBLIOGRAPHY}

Aroskar, MA 1994: Politics and Ethics in Nursing Implications for Education. Journal of Professional Nursing, 10(3), May-June.

Batra, C 1992: Empowering for Professional, Political, and Health Policy Involvement. Nursing Outlook, 40(4).

Brown, B 1996: Editorial Note. Nursing Administration Quarterly, 20(3).

Brennan, B 1993: Exploring new worlds: strategies for the future of nursing practice. Shaping Nursing Theory and Practice. 2nd National Conference MONOGRAPH 2.

Callahan, S 2000: Incorporating a political action framework into a BSN Program. Journal of Nursing Education, 39(1).

Chaska, NL 1990: The Nursing Profession. Turning Points. CV Mosby Company: Toronto.

Conger, CO \& Johnson, P 2000: Integrating Political Involvement and Nursing Education. Nurse Educator, 25(2) March/April.

De Thornyay, R 1993: Nursing Education. Staying on Track. Nursing and Health Care, 14(6), June.

Delougherry, GL 1995: Issues and Trends in Nursing; 2nd edition. Mosby: Toronto. 
Glen, S 1995: Towards a new model of Nursing Education. Nurse Education Today, 15(2).

Rains, JW \& Kelley, LC 2000: The effect of Health Policy Education on Self-perceived Political Competence of

Graduate Nursing Students. Journal of Nursing Education, 39(1).

Taylor, G 1995: Politics and nursing: an elective experience. Journal of Advanced Nursing, 21. 